\title{
Inhibition of DD-Peptidases by a Specific Trifluoroketone: Crystal Structure of a Complex with the Actinomadura R39 DD-Peptidase
}

Liudmila Dzhekieva, ${ }^{\dagger}$ S. A. Adediran, ${ }^{\dagger}$ Raphael Herman, ${ }^{\ddagger}$ Frédéric Kerff, ${ }^{\ddagger}$ Colette Duez, ${ }^{\ddagger}$ Paulette Charlier, ${ }^{\ddagger}$ Eric Sauvage, ${ }^{*}$ and R. F. Pratt ${ }^{*, \dagger}$

${ }^{\dagger}$ Department of Chemistry, Wesleyan University, Lawn Avenue, Middletown, Connecticut 06459, United States

${ }^{\ddagger}$ Centre d’Ingéniere des Protéines, Université de Liège, B-4000 Sart Tilman, Liège, Belgium

Supporting Information

ABSTRACT: Inhibitors of bacterial DD-peptidases represent potential antibiotics. In the search for alternatives to $\beta$-lactams, we have investigated a series of compounds designed to generate transition state analogue structures upon reaction with DDpeptidases. The compounds contain a combination of a peptidoglycan-mimetic specificity handle and a warhead capable of delivering a tetrahedral anion to the enzyme active site. The latter includes a boronic acid, two alcohols, an aldehyde, and a trifluoroketone. The compounds were tested against two low-molecular mass class C DD-peptidases. As expected from previous observations, the boronic acid was a potent inhibitor, but rather unexpectedly from precedent, the trifluoroketone [D- $\alpha$-aminopimelyl(1,1,1-trifluoro-3-amino)butan-2-one] was also very effective. Taking into account competing hydration, we found the trifluoroketone was the strongest inhibitor of the Actinomadura R39 DD-peptidase, with a subnanomolar (free

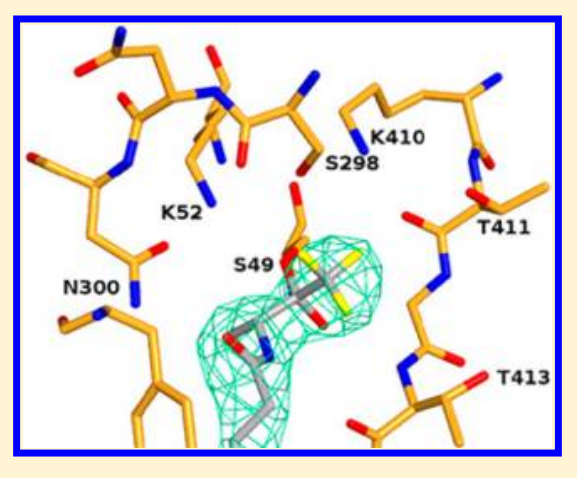
ketone) inhibition constant. A crystal structure of the complex between the trifluoroketone and the R39 enzyme showed that a tetrahedral adduct had indeed formed with the active site serine nucleophile. The trifluoroketone moiety, therefore, should be considered along with boronic acids and phosphonates as a warhead that can be incorporated into new and effective DD-peptidase inhibitors and therefore, perhaps, antibiotics.

$T^{\mathrm{k}}$ he bacterial DD-peptidases are of considerable importance in medical practice because they are the targets of $\beta$-lactam antibiotics. ${ }^{1}$ These enzymes catalyze the final transpeptidation reaction in the biosynthesis of bacterial cell walls and are essential to bacterial survival. The $\beta$-lactams, acting as mechanism-based, transition state analogue inhibitors, ${ }^{2-4}$ are precisely structured to inactivate DD-peptidases in a manner that these enzymes have been unable to escape through evolution of a hydrolytic pathway. Bacteria have, however, been able to achieve resistance to $\beta$-lactams in a number of ways unrelated to DD-peptidase active site structure and, in particular, through evolution of $\beta$-lactamases from DD-peptidases. ${ }^{2,4}$ The $\beta$-lactamases, unlike DD-peptidases, are able to catalyze rapid $\beta$-lactam hydrolysis and thus destruction of their antibiotic activity. 5

The rapid evolution of $\beta$-lactamases in response to new $\beta$-lactam antibiotics and also to $\beta$-lactam-based $\beta$-lactamase inhibitors $^{6-8}$ emphasizes the need for and stimulates the search for DD-peptidase inhibitors that are not $\beta$-lactam-based. ${ }^{9-15}$ One obvious approach is through transition state analogues, because such molecules should, in principle, inhibit any enzyme. ${ }^{16-18}$ Because the reactions catalyzed by DD-peptidases in vivo are acyl transfer reactions with a covalent acyl(serine)enzyme intermediate (Scheme 1), substrate-based tetrahedral anions covalently bound to the active site serine should be good analogues of the transition states of both acylation and deacylation steps. In principle, therefore, molecule 1, in which "peptidoglycan" is a specific peptidoglycan or peptidoglycanmimetic fragment and $\mathrm{X}$ is a reactive moiety that generates a tetrahedral anion upon reaction with the active site serine, would be the inhibitor of choice.

\section{Peptidoglycan - X \\ 1}

Approaches to 1 require the optimization of both peptidoglycan and X. One might expect that the former goal would be informed by studies of the substrate specificity of these enzymes, where a minimal, consensual, and thus broad spectrum peptidoglycan fragment would emerge. This goal has, however, not yet been achieved. It is true, of course, that peptidoglycan structure varies in detail between bacterial species, but even given this point, no consensual structure or class of privileged structures has emerged from consideration of DD-peptidase substrate specificity. ${ }^{19,20}$

DD-Peptidases have been classified structurally into two groups, the low-molecular mass (LMM) and high-molecular mass (HMM) enzymes. ${ }^{21}$ The latter group is essential for bacterial growth and contains the killing targets of $\beta$-lactams. Members of the former group are also inhibited by $\beta$-lactams

Received: January 11, 2013

Revised: February 17, 2013

Published: March 13, 2013 
Scheme 1

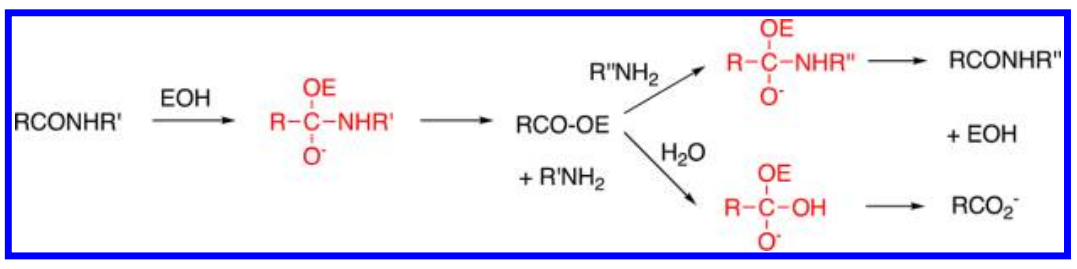

but are not essential for bacterial survival, in the short term at least. Both groups of enzymes are believed to catalyze acyl transfer reactions of peptidoglycan, viz., transpeptidase (HMM) and carboxypeptidase and endopeptidase (LMM) reactions. Certain members of the LMM group, subclasses $B$ and $C$, have been shown to have strong specificity for a free amine $\mathrm{N}$-terminus in peptidoglycan substrates, ${ }^{19,22-27}$ but no strong specificity for any particular element of peptidoglycan has been demonstrated for the HMM enzymes. ${ }^{13,19,24,28,29}$ The design of transition state analogue inhibitors for the latter enzymes is thus difficult.

With respect to element $\mathrm{X}$ of $\mathbf{1}$, some advances have been made. In particular, boronic acids (Scheme 2) have been shown

Scheme 2

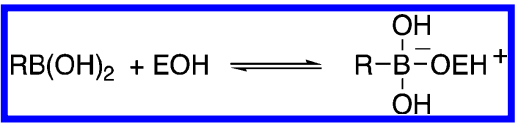

to be effective. Peptidoglycan-mimetic boronates have been found to be potent inhibitors of LMMC enzymes. ${ }^{13,20}$ The crystal structure of a complex of one such inhibitor, 2, with the LMMC Actinomadura R39 DD-peptidase demonstrated the reason for its specificity. ${ }^{13} \beta$-Lactam-mimetic boronic acids (bearing the amido side chains of classical $\beta$-lactam antibiotics rather than peptidoglycan) have also recently been found to be quite effective, although studies of them are limited. ${ }^{11,12,31}$

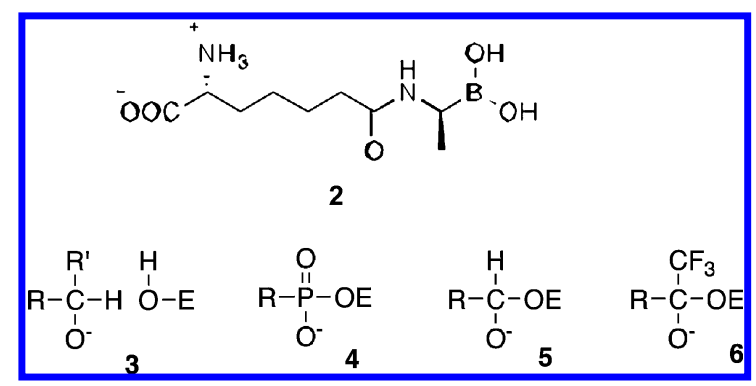

Beyond boronates, other sources of $\mathrm{X}$, employed with a variety of serine hydrolases, have been alcohols, phosphonates, aldehydes, and trifluoroketones, yielding, in principle, tetrahedral anions 3-6, respectively. ${ }^{32}$ Some assessment of the potential of these warheads with DD-peptidases has been made previously, ${ }^{14,33}$ although no indications of great potency have been observed. To date, the combination of motifs 3-6 with a specific peptidoglycan fragment (as in 1) has not been investigated. In this paper, we present the synthesis and assessment of the inhibitory activity of 7-12 versus representative LMMC DD-peptidases. We have discovered that trifluoroketone $\mathbf{1 2}$ is a potent inhibitor of the Actinomadura R39 enzyme and present a crystal structure of its complex with this enzyme.

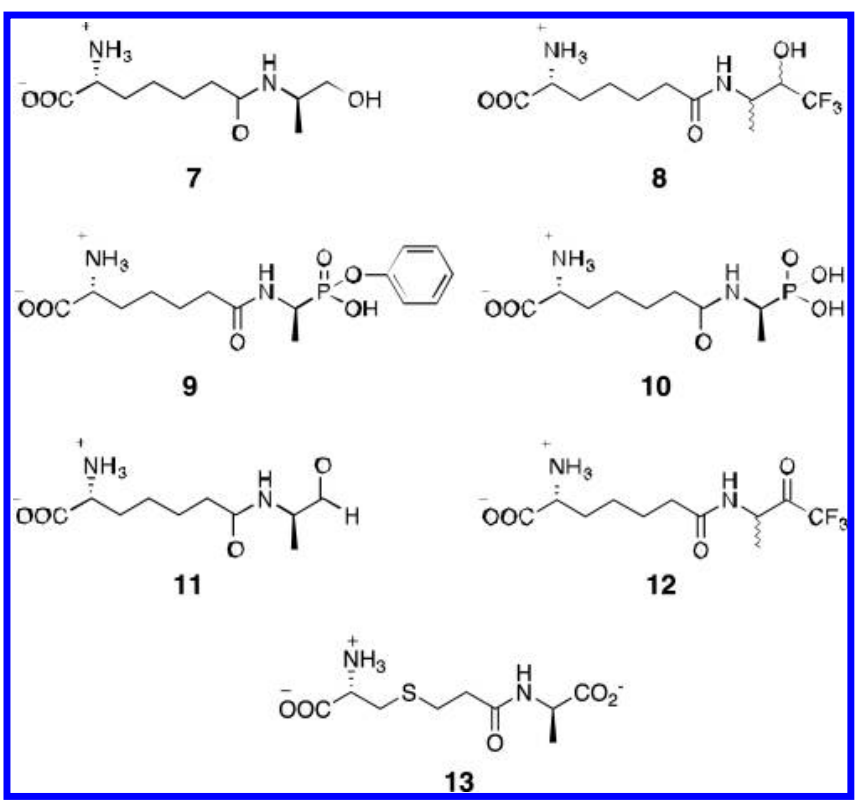

\section{MATERIALS AND METHODS}

Commercially available reagents and solvents were purchased from Aldrich and Acros Organics and used without purification, unless otherwise noted. D-Glutamic acid and $N-(Z)$-D-alanine were purchased from ChemImpex. Trifluoroacetaldehyde hydrate was purchased as a $75 \%$ solution in water from AlfaAesar. Compounds 24 (AlfaAesar), 25, and 27 were commercial products. Trifluoroketone 26 was synthesized in this laboratory by A. Shilabin. (Phenylacetyl)glycyl-Dthiolactate (14) and boronic acid 2 were synthesized as previously described. ${ }^{30}$ The Actinomadura R39 DD-peptidase<smiles>CC(C)CSC(=O)CNC(=O)Cc1ccccc1</smiles>

and Bacillus subtilis PBP4a were expressed and purified as described previously. ${ }^{34,35}$

Varian Mercury 300 and $400 \mathrm{MHz}$ NMR spectrometers were used to collect ${ }^{1} \mathrm{H},{ }^{31} \mathrm{P}$, and ${ }^{19} \mathrm{~F}$ NMR spectra. Absorption spectra and spectrophotometric reaction rates were measured with Hewlett-Packard 8452A and 8453 spectrophotometers. High-resolution mass spectra (HRMS) were obtained from the Mass Spectrometry Laboratory (School of Chemical Sciences, University of Illinois, Urbana, IL). Routine ESI mass spectra were recorded with a Thermo LCQ Advantage instrument. High-performance liquid chromatography purification was achieved by a Varian ProStar unit equipped with a Varian ProStar model 340 UV-vis detector and a Nucleosil C-18 reverse phase column (Macherey-Nagel). Flash column 
Scheme $3^{a}$

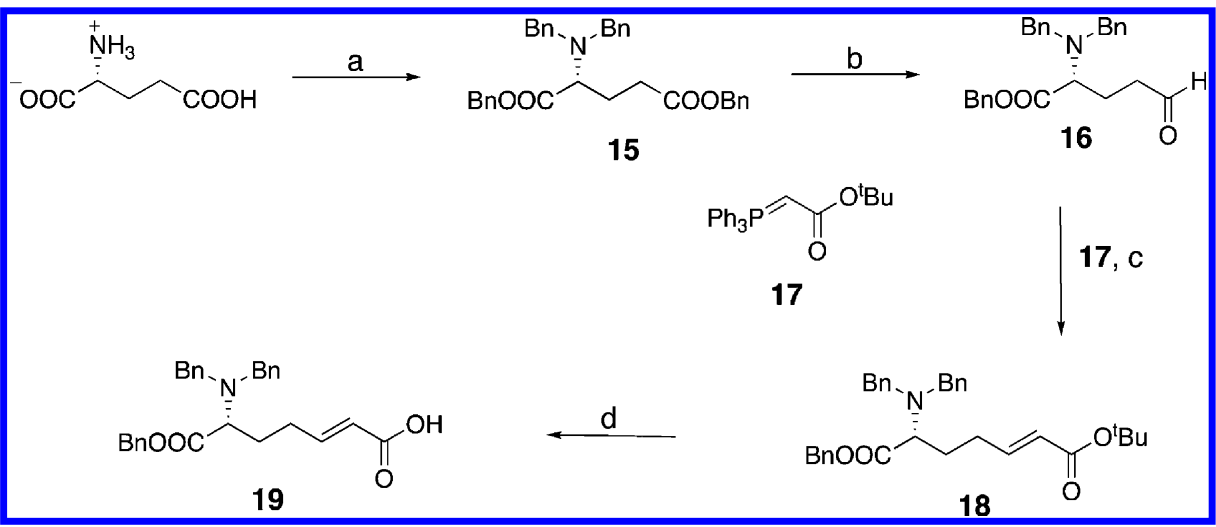

${ }^{a}$ Reagents and conditions: (a) BnBr, $\mathrm{NaOH}, \mathrm{K}_{2} \mathrm{CO}_{3}, \mathrm{H}_{2} \mathrm{O}$, reflux, 60\%; (b) DIBAL-H, Et ${ }_{2} \mathrm{O},-78{ }^{\circ} \mathrm{C}, 65 \%$; (c) $17, \mathrm{THF}, 25{ }^{\circ} \mathrm{C}, 1.5$ h; (d) TFA, $\mathrm{CH}_{2} \mathrm{Cl}_{2}, 0{ }^{\circ} \mathrm{C}, 1 \mathrm{~h}, 90 \%$.

\section{Scheme $4^{a}$}

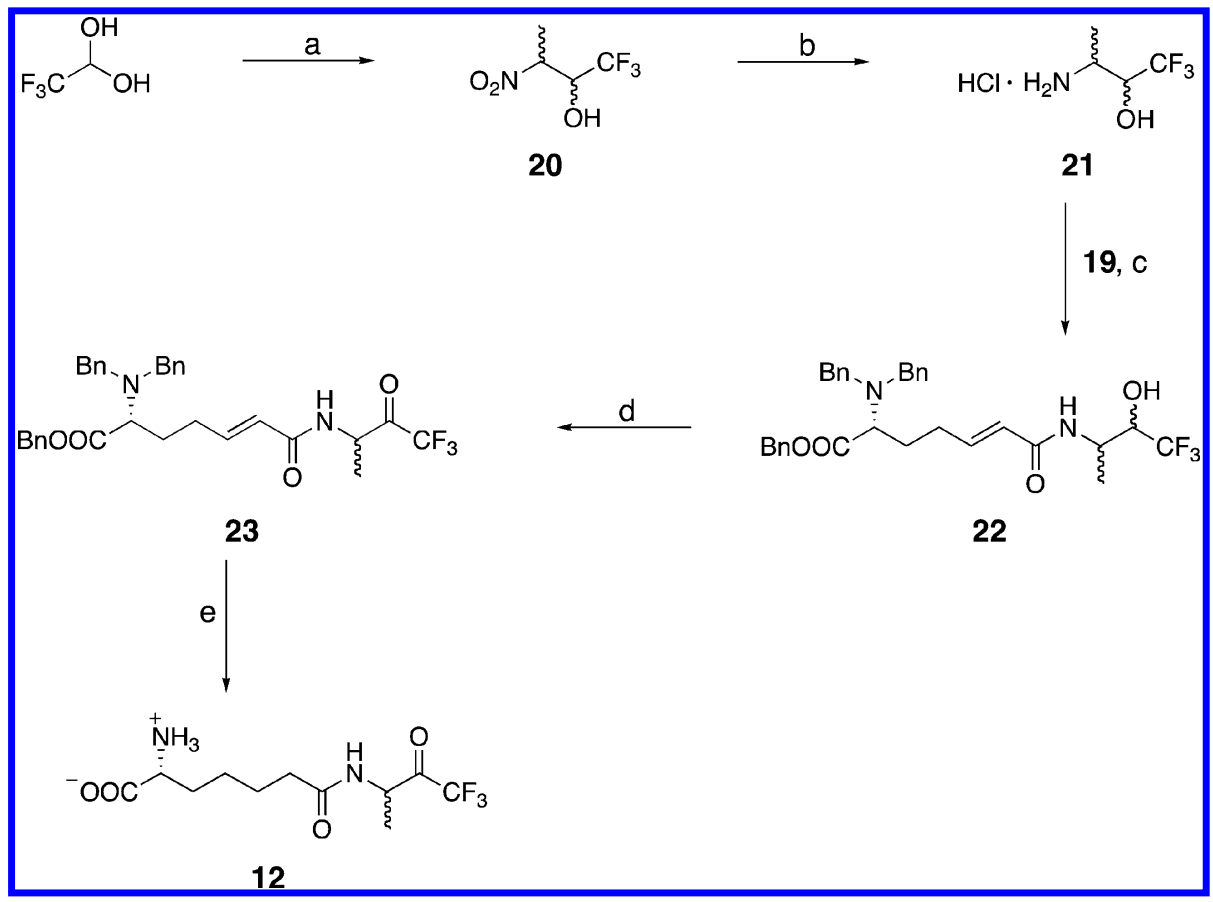

${ }^{a}$ Reagents and conditions: (a) nitroethane, $\mathrm{K}_{2} \mathrm{CO}_{3}, 50-60{ }^{\circ} \mathrm{C}, 3 \mathrm{~h}, 62 \%$; (b) $\mathrm{H}_{2}, 40$ psi, $10 \%$ (w/w) $\mathrm{PtO}_{2}, \mathrm{MeOH} / \mathrm{CHCl}{ }_{3}(16: 1), 12 \mathrm{~h}, 86 \%$; (c) 19, HBTU, $\mathrm{Et}_{3} \mathrm{~N}, 25^{\circ} \mathrm{C}, 24 \mathrm{~h}, 80 \%$; (d) Dess-Martin periodinane, TFA, $\mathrm{CH}_{2} \mathrm{Cl}_{2}, 25^{\circ} \mathrm{C}, 3 \mathrm{~h}, 90 \%$; (e) $\mathrm{H}_{2}, 40 \mathrm{psi}, 10 \%$ (w/w) Pd/C, MeOH, $12 \mathrm{~h}, 35 \%$.

chromatography was performed on Silicycle $60 \AA, 32-63 \mu \mathrm{m}$ silica gel.

Syntheses. D-6-( $N, N^{\prime}$-Dibenzylamino)-6-(benzyoxylcarbonyl)-trans-hex-2-enoic Acid 19 (Scheme 3). N,N-DibenzylD-glutamic Acid Dibenzyl Ester 15. This compound was synthesized following a previously reported general method. ${ }^{36}$ It was purified by chromatography on silica gel (7:1 hexane:ethyl acetate) producing 15 as a colorless oil in $60 \%$ yield: ${ }^{1} \mathrm{H}$ NMR $\left(\mathrm{CDCl}_{3}, 300 \mathrm{MHz}\right) \delta 2.1(\mathrm{q}, J=7.5 \mathrm{~Hz}, 2 \mathrm{H}), 2.43,2.56$ (d quint, $J=9,9 \mathrm{~Hz}, 2 \mathrm{H}), 3.47(\mathrm{t}, J=7.5 \mathrm{~Hz}, 1 \mathrm{H}), 3.55,3.93$ $(\mathrm{AB} q, J=13.5 \mathrm{~Hz}, 4 \mathrm{H}), 5.26(\mathrm{AB} q, J=3 \mathrm{~Hz}, 2 \mathrm{H}), 5.20,5.32$ $(\mathrm{AB} \mathrm{q} J=12 \mathrm{~Hz}, 2 \mathrm{H}), 7.25-7.46(\mathrm{~m}, 20 \mathrm{H})$.

D-4-(N,N-Dibenzylamino)-4-(benzyloxycarbonyl)butanal 16. To a stirred solution of 15 ( $3 \mathrm{~g}, 6 \mathrm{mmol}, 1$ equiv) in $30 \mathrm{~mL}$ of anhydrous diethyl ether under a nitrogen atmosphere was added DIBAL ( $1 \mathrm{M}$ in hexane, $6.5 \mathrm{~mL}, 1.1$ equiv) slowly at $-78^{\circ} \mathrm{C}$. The reaction mixture was stirred for $15 \mathrm{~min}$, and then water $(0.3 \mathrm{~mL})$ was added. The reaction mixture was allowed to warm to room temperature and stirred for an additional $30 \mathrm{~min}$; it was then dried over magnesium sulfate and filtered, and the volatiles were evaporated, leaving a colorless gum, 16 $(2.2 \mathrm{~g})$, which was employed in the next step without purification: ${ }^{1} \mathrm{H} \mathrm{NMR}\left(\mathrm{CDCl}_{3}, 300 \mathrm{MHz}\right) \delta 1.21(\mathrm{t}, J=7.8 \mathrm{~Hz}$, $2 \mathrm{H}), 2.3-2.5(\mathrm{~m}, 2 \mathrm{H}), 3.35(\mathrm{t}, J=7.2 \mathrm{~Hz}, 1 \mathrm{H}), 3.52,3.86$ $(\mathrm{AB} q, J=13.5 \mathrm{~Hz}, 4 \mathrm{H}), 5.20,5.26(\mathrm{AB} \mathrm{q}, J=10.8 \mathrm{~Hz}, 2 \mathrm{H})$, $7.2-7.5(\mathrm{~m}, 15 \mathrm{H}), 9.58(\mathrm{~s}, 1 \mathrm{H})$.

D-6-(N,N-Dibenzylamino)-6-(benzyloxycarbonyl)-transhex-2-enoic Acid tert-Butyl Ester 18. To a stirred solution of 16 (2.0 g, $5 \mathrm{mmol}, 1$ equiv) in dry THF $(20 \mathrm{~mL})$ was added (tert-butoxycarbonylmethylene)triphenylphosphorane 17 (Aldrich) (2.6 g, $6.8 \mathrm{mmol}, 1.2$ equiv) at room temperature. The reaction mixture was stirred for $1.5 \mathrm{~h}$, after which solvent was removed by evaporation. The crude product was purified by chromatography on silica gel (3:1 hexane:ethyl acetate), 
yielding product 18 as a colorless oil $(1.5 \mathrm{~g}, 60 \%$ yield $):{ }^{1} \mathrm{H}$ NMR ( $\left.\mathrm{CDCl}_{3}, 300 \mathrm{MHz}\right) \delta 1.47(\mathrm{~s}, 9 \mathrm{H}), 1.86(\mathrm{~m}, 2 \mathrm{H}), 2.07$ (m, $1 \mathrm{H}), 2.32(\mathrm{~m}, 1 \mathrm{H}), 3.34(\mathrm{t}, J=7.5 \mathrm{~Hz}, 1 \mathrm{H}), 3.53,3.87(\mathrm{AB}$ q, $J=13.5 \mathrm{~Hz}, 4 \mathrm{H}), 5.19,5.25(\mathrm{AB}$ q, $J=10.8 \mathrm{~Hz}, 2 \mathrm{H}), 5.59$ $(\mathrm{d}, J=16 \mathrm{~Hz}, 1 \mathrm{H}$ ), 6.70 (quint, $J=7.2 \mathrm{~Hz}, 1 \mathrm{H}$ ), $7.2-7.4$ $(\mathrm{m}, 15 \mathrm{H})$.

D-6-(N,N-Dibenzylamino)-6-(benzyloxycarbonyl)-transhex-2-enoic Acid 19. Ester 18 (0.5 g, $1 \mathrm{mmol})$ was dissolved in dichloromethane $(5 \mathrm{~mL})$. To this solution, stirred in an ice bath, was slowly added trifluoroacetic acid $(6 \mathrm{~mL})$. The reaction mixture was stirred for $1 \mathrm{~h}$ at room temperature, after which the solvent was evaporated. After the residue was dried under vacuum, product 19 was obtained as a gum $(0.4 \mathrm{~g}$, $90 \%$ yield): ${ }^{1} \mathrm{H}$ NMR $\left(\mathrm{CDCl}_{3}, 300 \mathrm{MHz}\right) \delta 1.86(\mathrm{~m}, 2 \mathrm{H}), 2.07(\mathrm{~m}$, $1 \mathrm{H}), 2.32(\mathrm{~m}, 1 \mathrm{H}), 3.34(\mathrm{t}, J=7.5 \mathrm{~Hz}, 1 \mathrm{H}), 3.53,3.87$ $(\mathrm{AB} q, J=13.5 \mathrm{~Hz}, 4 \mathrm{H}), 5.19,5.25(\mathrm{AB} \mathrm{q}, J=10.8 \mathrm{~Hz}, 2 \mathrm{H})$, 5.59 (d, $J=16 \mathrm{~Hz}, 1 \mathrm{H}$ ), 6.7 (quint, $J=7.2 \mathrm{~Hz}, 1 \mathrm{H}$ ), 7.2-7.4 (m, 15H); ES(+)MS m/z $444.4(\mathrm{M}+1)$.

$D$ - $\alpha$-Aminopimelyl(1,1,1-trifluoro-3-amino)butan-2-one (Scheme 4). 3-Nitro-1,1,1-trifluoro-2-butanol 20. This compound was prepared following the procedure reported by McBee et al. ${ }^{37}$

Product 20 was obtained as a yellow oil in $62 \%$ yield: ${ }^{1} \mathrm{H}$ NMR $\left(300 \mathrm{MHz}, \mathrm{CDCl}_{3}\right) \delta 1.72(\mathrm{~d}, 3 \mathrm{H}, J=6 \mathrm{~Hz}), 3.2-3.6$ (br s, $1 \mathrm{H}), 4.76-4.92(\mathrm{~m}, 2 \mathrm{H})$.

3-Amino-1,1,1-trifluoro-2-butanol Hydrochloride 21. This compound was prepared as a mixture of diastereoisomers, following the procedure reported by Shao et al. ${ }^{38}$ The colorless solid hydrochloride salt was obtained in $86 \%$ yield: ${ }^{1} \mathrm{H}$ NMR $\left(300 \mathrm{MHz}, d_{6}\right.$-DMSO) $\delta 1.20(\mathrm{~d}, J=4.8 \mathrm{~Hz}, 3 \mathrm{H}), 1.27(\mathrm{~d}, 3 \mathrm{H}$, $J=4.8 \mathrm{~Hz}), 3.40(\mathrm{~m}, 1 \mathrm{H}), 3.53(\mathrm{~m}, 1 \mathrm{H}), 4.14(\mathrm{~m}, 1 \mathrm{H}), 4.38$ (m, $1 \mathrm{H}), 8.06$ (br s, $3 \mathrm{H}), 8.22$ (br s, $3 \mathrm{H})$.

D-1-[6-(N,N-Dibenzylamino)-6-(benzyloxycarbonyl)]-transhex-2-enoyl-3-amino-1,1,1-trifluoro-2-butanol 22. To a mixture of D-1-[6-(N,N-dibenzylamino)-6-(benzyloxycarbonyl)]trans-hex-2-enoic acid 19 (488 mg, $1.1 \mathrm{mmol}, 1$ equiv) and 3-amino-1,1,1-trifluoro-2-butanol hydrochloride 21, dissolved in $10 \mathrm{~mL}$ of DMF, was added triethylamine $(767 \mu \mathrm{L}, 2.75$ mmol, 2.5 equiv) followed by HBTU (1046 mg, $2.75 \mathrm{mmol}$, 2.5 equiv) at $0-5{ }^{\circ} \mathrm{C}$. The reaction mixture was stirred at room temperature for $24 \mathrm{~h}$. The solvent was removed in vacuo and the residue dissolved in ethyl acetate. The organic solution was washed with $0.1 \mathrm{M}$ hydrochloric acid, a saturated aqueous solution of sodium bicarbonate, and brine and dried over anhydrous sodium sulfate. The solvent was removed in vacuo, and the residue was purified by silica gel column chromatography (ethyl acetate/hexane) to give product $\mathbf{2 2}$ in $80 \%$ yield as a colorless oil: ${ }^{1} \mathrm{H}$ NMR (400 MHz, $\left.\mathrm{CDCl}_{3}\right) \delta 1.32(\mathrm{~d}, 3 \mathrm{H}, J=7.5 \mathrm{~Hz})$, $1.76(\mathrm{~m}, 2 \mathrm{H}), 2.06-2.16(\mathrm{~m}, 1 \mathrm{H}), 2.25-2.36(\mathrm{~m}, 1 \mathrm{H}), 3.32$ $(\mathrm{dd}, J=6 \mathrm{~Hz}, 1 \mathrm{H}), 3.46,3.85(\mathrm{AB} \mathrm{q}, J=16 \mathrm{~Hz}, 4 \mathrm{H}), 4.07(\mathrm{~m}, 1 \mathrm{H})$, $4.28(\mathrm{~m}, 1 \mathrm{H}), 4.83(\mathrm{~d}, J=7.5 \mathrm{~Hz}, 1 \mathrm{H}), 4.91(\mathrm{~d}, J=7.5 \mathrm{~Hz}, 1 \mathrm{H})$, $5.21(\mathrm{AB} \mathrm{q} J=16,24 \mathrm{~Hz}, 2 \mathrm{H}), 5.40(\mathrm{~d}, J=5 \mathrm{~Hz}, 1 \mathrm{H}), 7.67$ $(\mathrm{m}, 1 \mathrm{H}), 7.2-7.4(\mathrm{~m}, 15 \mathrm{H})$.

D-1-[6-(N,N-Dibenzylamino)-6-(benzyloxycarbonyl)]-transhex-2-enoyl-3-amino-1,1,1-trifluorobutan-2-one 23. To a stirred solution of 22 (380 mg, $0.67 \mathrm{mmol}, 1$ equiv) in dichloromethane $(25 \mathrm{~mL})$ at room temperature was added Dess-Martin periodinane $(850 \mathrm{mg}, 2 \mathrm{mmol}, 3$ equiv), followed by trifluoroacetic acid $(150 \mu \mathrm{L}, 2 \mathrm{mmol}, 3$ equiv) at room temperature. The reaction mixture was stirred for $3 \mathrm{~h}$, after which it was quenched with a sodium bicarbonate solution and extracted with ethyl acetate. After the solution had been dried and the solvent evaporated, the crude product was purified on a silica gel column (1:1 ethyl acetate/hexane), and product 23 was isolated in $90 \%$ yield as a colorless oil: ${ }^{1} \mathrm{H}$ NMR (400 $\left.\mathrm{MHz}, \mathrm{CDCl}_{3}\right) \delta 1.39(\mathrm{~d}, J=8 \mathrm{~Hz}, 3 \mathrm{H}), 1.46(\mathrm{~d}, J=8 \mathrm{~Hz}, 3 \mathrm{H})$, $1.75-1.96(\mathrm{~m}, 2 \mathrm{H}), 2.06-2.18(\mathrm{~m}, 1 \mathrm{H}), 2.24-2.36(\mathrm{~m}, 1 \mathrm{H})$, $3.31(\mathrm{~m}, 1 \mathrm{H}), 3.49,3.86(\mathrm{AB} \mathrm{q}, J=16 \mathrm{~Hz}, 4 \mathrm{H}), 4.11(\mathrm{~m}, 1 \mathrm{H})$, $4.88-5.06(\mathrm{dd}, J=8 \mathrm{~Hz}, 1 \mathrm{H}), 5.2(\mathrm{AB} q, J=16,24 \mathrm{~Hz}, 2 \mathrm{H})$, $5.70(\mathrm{~d}, J=6 \mathrm{~Hz}, 1 \mathrm{H}), 7.69(\mathrm{~m}, 1 \mathrm{H}), 7.23(\mathrm{~s}, 10 \mathrm{H}), 7.4$ (s, $5 \mathrm{H})$.

D- $\alpha$-Aminopimelyl(1,1,1-trifluoro-3-amino)butan-2-one 12. The required final product was prepared from 23 by catalytic hydrogenation overnight at $40 \mathrm{psi}$ in $10 \mathrm{~mL}$ of $\mathrm{MeOH}$ with $10 \% \mathrm{Pd}$ on carbon. After reaction, the solution was filtered, and the filtrate was evaporated to dryness to give a colorless solid. The crude product was dissolved in water and washed with ethyl acetate three times. The aqueous solution was separated and freeze-dried to give a colorless solid. This was purified by two passages through a Sephadex G10 sizeexclusion chromatography column (water eluent). Product 12 was isolated in $35 \%$ yield as a colorless solid: ${ }^{1} \mathrm{H}$ NMR $\left(400 \mathrm{MHz}, \mathrm{D}_{2} \mathrm{O}\right) \delta 1.06(\mathrm{~d}, J=6.8 \mathrm{~Hz}, 3 \mathrm{H}), 1.22(\mathrm{~m}, 2 \mathrm{H})$, $1.46(\mathrm{~m}, 2 \mathrm{H}), 1.70(\mathrm{~m}, 2 \mathrm{H}), 2.12(\mathrm{t}, J=7.5 \mathrm{~Hz}, 2 \mathrm{H}), 3.56$ $(\mathrm{t}, J=6 \mathrm{~Hz}, 1 \mathrm{H}), 4.15(\mathrm{q}, J=7.2 \mathrm{~Hz}, 1 \mathrm{H}) ;{ }^{19} \mathrm{~F}$ NMR $(300$ $\left.\mathrm{MHz}, \mathrm{D}_{2} \mathrm{O}\right) \delta-82\left(\mathrm{CF}_{3}\right)$; HRMS (ESI) $[\mathrm{M}+\mathrm{H}]^{+}$found 299.1220 , calcd 299.1219 .

Syntheses of 7-11 are described in detail in the Supporting Information.

Enzyme Kinetics Studies. Inhibition of the Actinomadura R39 DD-Peptidase by Compounds 7-12. In view of the nature of the inhibitors and all precedent, ${ }^{20,24-26}$ the inhibition was interpreted in all cases as purely competitive. Equilibrium constants for inhibition of the R39 DD-peptidase by compounds 7 (0-3.0 mM), $10(0-2.0 \mathrm{mM}), 11(0-1.0 \mathrm{mM}), 8(0-$ $400 \mu \mathrm{M}), 9(0-2.0 \mathrm{mM})$, and $12(0-40 \mu \mathrm{M})$ were obtained from steady state competition experiments in which 14 was employed as a chromogenic $\left(245 \mathrm{~nm} ; \Delta \varepsilon=2500 \mathrm{~cm}^{-1} \mathrm{M}^{-1}\right.$ ) substrate $(0.5 \mathrm{mM})$. The reaction conditions were $20 \mathrm{mM}$ MOPS buffer, $\mathrm{pH} 7.50,25^{\circ} \mathrm{C}$, and an enzyme concentration of $210 \mathrm{nM}$. Under these conditions, the $K_{\mathrm{m}}$ value of the substrate was $38.4 \mu \mathrm{M}^{25}$ Measurements of the initial velocity versus concentrations of 7-11 were fit to Scheme 5 and eq 1 to obtain

\section{Scheme 5}

\begin{tabular}{|lll}
$E+S$ & $\rightleftharpoons \mathrm{K}_{m}$ & $E S$ \\
$E S$ & $\stackrel{\mathrm{K}_{2}}{\longrightarrow}$ & $E+P$ \\
$E+I$ & $\rightleftharpoons$ &
\end{tabular}

the $K_{\mathrm{i}}$ value. Total progress curves of inhibition of R39 DDpeptidase by compound 12 were fit to Scheme 8 (see below) with Dynafit ${ }^{39}$ to obtain the $K_{\mathrm{i}}$ value directly.

$$
v_{0}=V\left(K_{\mathrm{m}}+s\right) /\left[K_{\mathrm{m}}\left(1+i / K_{\mathrm{i}}\right)+s\right]
$$

Inhibition of $B$. subtilis PBP4a by Compounds 7-12. Equilibrium constants for inhibition of $B$. subtilis PBP4a by compounds 7-12 were obtained in a manner similar to that used for the constants for the R39 enzyme. The reaction con-

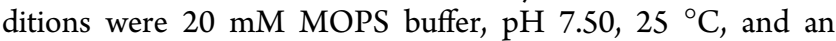
enzyme concentration of $164 \mathrm{nM}$. Under these conditions, $K_{\mathrm{m}}$ was $0.44 \pm 0.08 \mathrm{mM}$ for $\mathbf{1 4}$ as a substrate. The total progress curves for inhibition by compounds $8(0-400 \mu \mathrm{M}), 11(0-1.0 \mathrm{mM})$, 
and $12(0-40 \mu \mathrm{M})$ were fit to Scheme 5 with Dynafit ${ }^{39}$ to obtain $K_{\mathrm{i}}$ values.

The $K_{\mathrm{i}}$ values for 24-27 with both enzymes were obtained from the measurement of initial rates at several concentrations of inhibitor in each case and application of eq 1 .

Kinetics of Aminolysis of 14 by 7-10, Catalyzed by the R39 DD-Peptidase. Aminolysis of substrate 14 by amines 7-12, catalyzed by the R39 DD-peptidase, involves amine attack on the acyl-enzyme E-S intermediate (Scheme 6). The initial rates of

Scheme 6

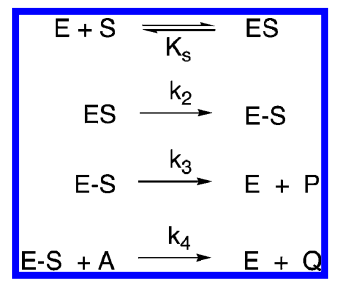

reaction of 14, catalyzed by this enzyme, as a function of concentrations of 7-10 were fit to Scheme 6 with Dynafit. ${ }^{39}$ These experiments were conducted in $20 \mathrm{mM}$ MOPS buffer at $\mathrm{pH} 7.50$ and $25{ }^{\circ} \mathrm{C}$ with an enzyme concentration of $210 \mathrm{nM}$.

Crystallization, Data Collection, and Structure Determination. Crystals of the enzyme were obtained by the hanging drop vapor diffusion method by mixing $4 \mu \mathrm{L}$ of a $25 \mathrm{mg} / \mathrm{mL}$ protein solution [also containing $5 \mathrm{mM} \mathrm{MgCl}_{2}$ and $20 \mathrm{mM}$ Tris ( $\mathrm{pH} 8.0)$ ], $2 \mu \mathrm{L}$ of a well solution [2.0 M ammonium sulfate and 0.1 M MES (pH 6)], and $0.5 \mu \mathrm{L}$ of $0.1 \mathrm{M} \mathrm{CoCl}_{2}$. Crystals were soaked in $6 \mu \mathrm{L}$ of a solution containing $3.0 \mathrm{M}$ ammonium sulfate, 0.1 M MES ( $\mathrm{pH} 6.0$ ), and $0.5 \mu \mathrm{L}$ of $0.5 \mathrm{M} 12$.

Data for the R39-12 crystals were measured on beamline PROXIMA at SOLEIL (Paris, France) and processed using XDS. Molecular replacement processed with the native structure produced an interpretable density map, which clearly shows 12 in the four monomers of the asymmetric unit. Refinement was conducted with Refmac, ${ }^{40}$ Coot, $^{41}$ and TLS $^{42}$ with final $R$ and $R_{\text {free }}$ values of 19.3 and $23.7 \%$, respectively. Data collection and refinement statistics are summarized in Table 1.

\section{RESULTS AND DISCUSSION}

Synthesis of the new compounds 7-12 was achieved in a straightforward fashion (Schemes 3 and 4 and Schemes S1-S5 of the Supporting Information) via the versatile intermediate 19. They were all characterized by NMR and MS methods. All, along with the carboxylate 13 and simple functional group analogues 24-27, were treated as rapid equilibrium competitive inhibitors of two LMMC DD-peptidases, the Actinomadura R39 DD-peptidase and B. subtilis PBP4a. No indications of slow binding were observed in any case. Values of the inhibition constant, $K_{\mathrm{i}}$, obtained for 7-12, along with those for 2 and 13, previously determined, ${ }^{30}$ are as reported in Table 2.

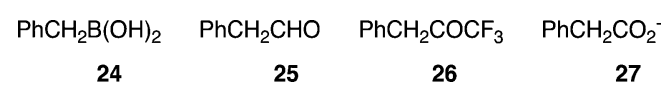

Alcohols 7 and $\mathbf{8}$ had very little inhibitory activity against either enzyme. Even the trifluoromethyl substituent of $\mathbf{8}$, which should reduce the alcohol $\mathrm{pK}_{\mathrm{a}}$ into a range where its anion would be accessible to the active site oxyanion hole, produced only a weak inhibitor of PBP4a. Configuration 3 of alcohols at
Table 1. Data Collection and Refinement Statistics

\begin{tabular}{|c|c|}
\hline \multicolumn{2}{|c|}{ Data Collection ${ }^{a}$} \\
\hline space group & $P 2_{1}$ \\
\hline cell dimensions & $\begin{array}{c}a=103.6 \AA, b=91.7 \AA, c=106.9 \AA \text {, } \\
\beta=94.30^{\circ}\end{array}$ \\
\hline resolution range $(\AA)$ & $48.9-2.6(2.74-2.6)$ \\
\hline no. of unique reflections & 61653 \\
\hline$R_{\text {merge }}(\%)^{b}$ & $9.4(63.2)$ \\
\hline redundancy & $6.9(6.9)$ \\
\hline completeness (\%) & $100(100)$ \\
\hline$\langle I\rangle /\langle\sigma I\rangle$ & $13.5(3.3)$ \\
\hline \multicolumn{2}{|c|}{ Refinement } \\
\hline resolution range $(\AA)$ & $47.9-2.6$ \\
\hline no. of non-hydrogen protein atoms & 13891 \\
\hline no. of water molecules & 322 \\
\hline$R_{\text {cryst }}(\%)$ & 19.3 \\
\hline$R_{\text {free }}(\%)$ & 23.7 \\
\hline \multicolumn{2}{|l|}{$\begin{array}{l}\text { root-mean-square deviation from ideal } \\
\text { stereochemistry }\end{array}$} \\
\hline bond lengths $(\AA)$ & 0.007 \\
\hline bond angles (deg) & 1.00 \\
\hline mean $B$ factor (all atoms) $\left(\AA^{2}\right)$ & 60.7 \\
\hline mean $B$ factor (ligands) $\left(\AA^{2}\right)$ & 45.0 \\
\hline \multicolumn{2}{|l|}{ Ramachandran plot $^{c}$} \\
\hline favored regions (\%) & 96.9 \\
\hline allowed regions (\%) & 3.1 \\
\hline outlier regions (\%) & 0.0 \\
\hline PDB entry & $3 z c z$ \\
\hline
\end{tabular}

${ }^{a}$ Statistics for the highest-resolution shell are given in parentheses. ${ }^{b} R_{\text {merge }}=\sum\left|I_{\mathrm{i}}-I_{\mathrm{m}}\right| / \sum I_{\mathrm{i}}$, where $I_{\mathrm{i}}$ is the intensity of the measured reflection and $I_{\mathrm{m}}$ is the mean intensity of all symmetry-related reflections. Values in parentheses are for the outer resolution shell. ${ }^{c}$ Using rampage. ${ }^{63}$

Table 2. Inhibition of DD-Peptidases by Specific Inhibitors

\begin{tabular}{|c|c|c|c|}
\hline \multirow[b]{2}{*}{ inhibitor } & \multicolumn{2}{|c|}{ R39 } & \multirow{2}{*}{$\begin{array}{c}\text { РВР4a } \\
K_{\mathrm{i}}(\mu \mathrm{M})\end{array}$} \\
\hline & $K_{\mathrm{i}}(\mu \mathrm{M})$ & $k_{4}\left(\mathrm{~s}^{-1} \mathrm{M}^{-1}\right)$ & \\
\hline \multirow[t]{2}{*}{2} & $0.032^{a}(0.5)^{b}$ & $\mathrm{NO}^{d}$ & $0.007 \pm 0.001$ \\
\hline & $0.057 \pm 0.001^{c}$ & & \\
\hline 7 & $6700 \pm 100^{c}(3000)$ & $(6.1 \pm 0.4) \times 10^{3}$ & $>1000(1000)$ \\
\hline 8 & $1250 \pm 50^{c, e}(500)$ & $(2.1 \pm 0.1) \times 10^{4}$ & $(110 \pm 25)^{e}(300)$ \\
\hline 9 & $\mathrm{NI}^{c^{c f}}(2000)$ & $(2.9 \pm 0.1) \times 10^{2}$ & $\mathrm{ND}^{g}$ \\
\hline 10 & $\mathrm{NI}^{c, f}(2000)$ & $\leq 1.0 \times 10^{2}$ & $\mathrm{ND}^{g}$ \\
\hline $11^{h}$ & $(76 \pm 13)(1000)$ & $\mathrm{NO}^{d}$ & $(500 \pm 150)(1000)$ \\
\hline \multirow[t]{2}{*}{$12^{h}$} & $(0.37 \pm 0.04)^{i}$ & $(2.2 \pm 0.1) \times 10^{3}$ & $(13.5 \pm 0.3)^{i}(300)$ \\
\hline & $(0.17 \pm 0.02)^{c, i}$ & & \\
\hline 13 & $480^{j}$ & $3.0 \times 10^{3 j}$ & $\mathrm{ND}^{g}$ \\
\hline
\end{tabular}

${ }^{a}$ From ref $30 .{ }^{b}$ Highest inhibitor concentration (micromolar) employed in parentheses. ${ }^{c}$ Fluorescence experiment (see the text). ${ }^{d}$ No rate acceleration observed at the highest concentration employed. ${ }^{e}$ Observed value divided by 4 , because it is assumed that only one of the four diastereomers present has significant activity (see the text). ${ }^{f}$ No inhibition observed at the highest concentration employed. ${ }^{g}$ Not determined. ${ }^{h} K_{\mathrm{i}}$ values not corrected for hydration; see the text for corrected values. ${ }^{i}$ Observed value divided by 2 , because it is assumed that only one of the two diastereomers present has significant activity (see the text). ${ }^{j}$ From ref 25 .

the active site is therefore unfavorable. It should be noted in passing that alcohol $\mathbf{8}$ was obtained as a mixture of four diastereoisomers in roughly equal amounts (see the ${ }^{19} \mathrm{~F}$ NMR data in the Supporting Information), only one of which would be expected to be an inhibitor $(2 R, 3 S)$. Serine hydrolases, in 
general, are not efficiently inhibited by alcohols, even when specific (e.g., refs 43 and 44). Phosphonates 9 and 10 were also ineffective against the DD-peptidases. Presumably, configuration 28 is not favorable either. A series of arylamidophosphonic acids was also found to lack significant inhibitory activity against the R39 DD-peptidase. ${ }^{12}$ Specific aryl phosphonate esters are known to be time-dependent covalent inhibitors of $\beta$-lactamases ${ }^{45}$ and (weakly) of a LMMB DD-peptidase. ${ }^{46}$ No time-dependent inhibition of the present LMMC DD-peptidases by 9 , however, was observed.

$$
\begin{array}{cc}
\mathrm{PhO} / \mathrm{O}^{-} & \mathrm{H} \\
\mathrm{R}-\mathrm{P}^{-}= & \mathrm{O}^{-}-\mathrm{E} \\
\mathrm{O}^{-} &
\end{array}
$$$$
28
$$

Carboxylate $\mathbf{1 3}$ is also a weak inhibitor of the R39 enzyme (Table 2). The trigonal carboxylate apparently does not sit well in the oxyanion hole. This is, in fact, seen in the crystal structure of a complex of the carba analogue of $\mathbf{1 3}$ with the R39 DD-peptidase, ${ }^{26}$ where the carboxylate is oriented away from the oxyanion hole. It is certainly reasonable that 13 , the product of a DD-carboxypeptidase or endopeptidase reaction, would be a poor inhibitor.

Both of the specific carbonyl compounds 11 and 12 are inhibitors of both LMMC enzymes. Trifluoroketone $\mathbf{1 2}$ is particularly effective (it is assumed that only one of the two diasteromers of 12, present in approximately equal amounts, has significant activity; this isomer, seen in the crystal structure described below, has D-stereochemistry at the ketone terminus). It is likely (also see below) that these carbonyl compounds form tetrahedral adducts 4 and 5, respectively, at the active site. The greater effectiveness of the trifluoroketone is likely to be due in part to the higher alcohol acidity of the adduct, ${ }^{47}$ allowing thermodynamically more favorable formation of 6 than 5 at $\mathrm{pH} 7.5\left(\mathrm{p} K_{\mathrm{a}}\right.$ values of trifluoroethanol and ethanol are 12.4 and $16,{ }^{48}$ respectively, favoring anion formation by the former by a factor of $10^{3.6}$ ). This factor is essentially sufficient to rationalize the higher inhibitory potency of $\mathbf{1 2}$ compared to that of 11 .

If it is assumed that the reacting species of $\mathbf{1 1}$ and $\mathbf{1 2}$ are the free carbonyls, ${ }^{47}$ then the observed or apparent $K_{\mathrm{i}}$ values of Table 2 should be corrected for the competing hydration in aqueous solution (Scheme 7 ) via eq 2

$$
K_{\mathrm{H}}=\left[\mathrm{IOH}_{2}\right] /[\mathrm{I}] \quad K_{\mathrm{i}}=K_{\mathrm{i}}^{\mathrm{obs}} /\left(1+K_{\mathrm{H}}\right)
$$

Scheme 7

$$
\begin{aligned}
& \begin{array}{l}
\mathrm{E}+\mathrm{I} \underset{\mathrm{K}_{\mathrm{i}}}{\rightleftharpoons} \mathrm{EI} \\
\| \mathrm{K}_{\mathrm{H}}
\end{array} \\
& \mathrm{IOH}_{2}
\end{aligned}
$$

where $K_{\mathrm{i}}^{\mathrm{obs}}$ is the observed value. From ${ }^{1} \mathrm{H}$ NMR spectra (not shown), $K_{\mathrm{H}}$ for 11 is 30 , and therefore, from eq 2 , the "real" $K_{\mathrm{i}}$ values for the carbonyl form of 11 are 2.5 and $16.1 \mu \mathrm{M}$ for the R39 DD-peptidase and PBP4a, respectively. The effect of hydration is even more dramatic with 12. Although estimates of $K_{\mathrm{H}}$ for trifluoroacetone in the literature are curiously wideranging, ${ }^{47,49,50}$ the lower limit estimate is $35 .{ }^{49}$ If the additional effect of the amido substituent is included as a factor of 30 (estimated from the $K_{\mathrm{H}}$ values of acetaldehyde ${ }^{49}$ and 11), then a lower limit estimate of $K_{\mathrm{H}}$ for $\mathbf{1 2}$ would be 1000 . Certainly, we are unaware of any report in the literature of NMR observation of the carbonyl form of a $\alpha$-trifluoro- $\alpha^{\prime}$-amidoketone in aqueous solution (e.g., refs 51 and 52). Thus, $K_{\mathrm{i}}$ values for 12, corrected for hydration, can be estimated to be 0.37 and $13.5 \mathrm{nM}$ for the R39 DD-peptidase and PBP4a, respectively. These estimates represent upper limits and may be an order of magnitude larger than the real values. These carbonyl compounds are certainly powerful inhibitors of the LMMC DDpeptidases and, upon reaction with the enzymes, may well generate structures resembling tetrahedral high-energy intermediates or transition states (see below).

The lack of specificity of the trifluoromethyl moiety itself and the importance of the specific $\mathrm{N}$-terminus are confirmed by the data listed in Table 3, where the effectiveness of generic

Table 3. Inhibition of DD-Peptidases by Generic Inhibitors

\begin{tabular}{cll} 
& \multicolumn{2}{c}{$K_{\mathrm{i}}(\mathrm{mM})$} \\
\cline { 2 - 3 } inhibitor & \multicolumn{1}{c}{$\mathrm{R} 39$} & \multicolumn{1}{c}{ PBP4a } \\
24 & $\mathrm{NI}^{a}(3.0)^{b}$ & $(0.23 \pm 0.03)(3.0)$ \\
25 & $\mathrm{NI}^{a}(2.5)$ & $\mathrm{ND}^{c}$ \\
26 & $(0.27 \pm 0.06)(2.0)$ & $5.0 \pm 1.6(3.0)$ \\
27 & $\mathrm{NI}^{a}(2.5)$ & $\mathrm{ND}^{c}$
\end{tabular}

${ }^{a}$ No inhibition observed. ${ }^{b}$ Highest inhibitor concentration (millimolar) employed in parentheses. ${ }^{c}$ Not determined.

inhibitors 24-27, bearing the "warheads" of 2, 7, 11, and 12, respectively, is displayed. Only 26 shows weak inhibition of the R39 DD-peptidase as do 24 and 26 of PBP4a.

It was striking that the weaker "inhibitors" of the R39 DDpeptidase, 7-9, actually produced an increase in the initial rate of substrate turnover, as shown for 7 in Figure 1, for example.

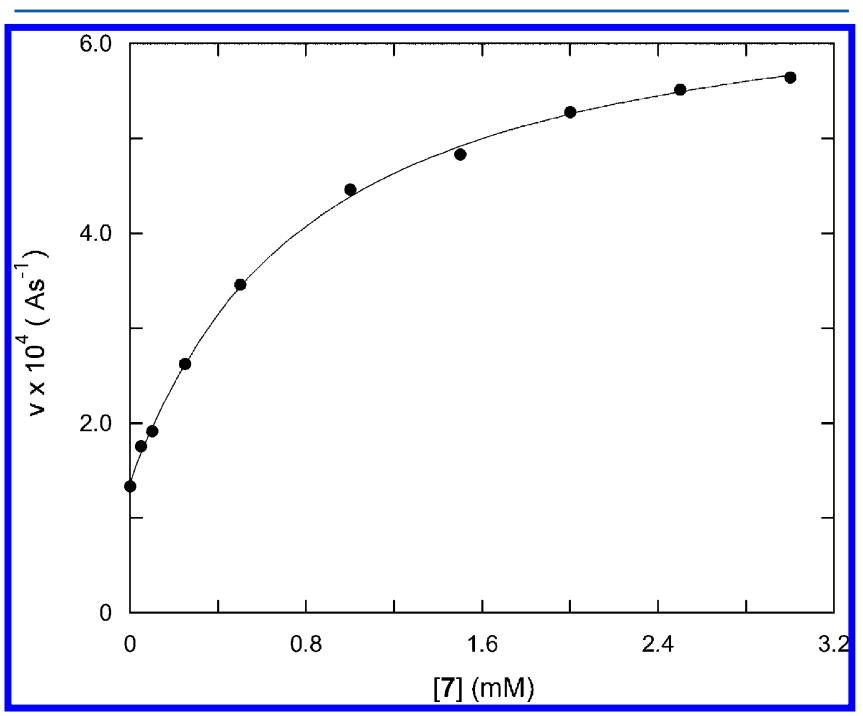

Figure 1. Effect of alcohol 7 on initial rates of turnover of thiolester substrate $14(0.5 \mathrm{mM})$ catalyzed by the R39 DD-peptidase. The points are experimental, and the line represents the fit of the data to Scheme 6 (see the text).

The likely explanation for this, with established precedent, ${ }^{25}$ is that, because of their free D-amino acid termini, these compounds may also act as acyl acceptors and, in cases where enzyme deacylation is rate-determining, as is presumably true for thiolester 14, accelerate the observed reaction. Data like 
those shown in Figure 2 were fit to Scheme 6 to obtain values for $k_{4}$ (Table 2). Obviously, the $k_{4}$ values for 7 and 8 are much higher than for the anionic $\mathbf{9}$ and $\mathbf{1 0}$ and are comparable to that $\left(1.4 \times 10^{4} \mathrm{~s}^{-1} \mathrm{M}^{-1}\right)$ of the best acceptor yet discovered for this enzyme, the good substrate $29 .{ }^{25}$ It is, however, striking that anionic terminal carboxylate $\mathbf{1 3}$ is a much better acceptor than the equally anionic phosphonates 9 and 10. The ability of enzymes to bind carboxylates and phosph(on)ates differently has been noticed previously, ${ }^{53}$ although the functional significance of the distinction here is not evident.

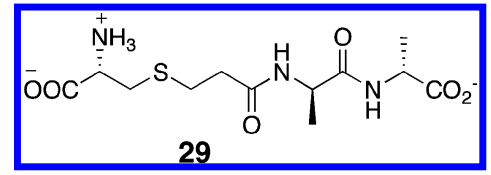

The acyl acceptor ability of these inhibitors probably also led to the initially unexpected observation of an apparent decrease in the effectiveness of $\mathbf{1 2}$ as an inhibitor of the R39 DDpeptidase as a function of time in experiments with substrate 14 (Figure 2). This phenomenon can be interpreted in terms of

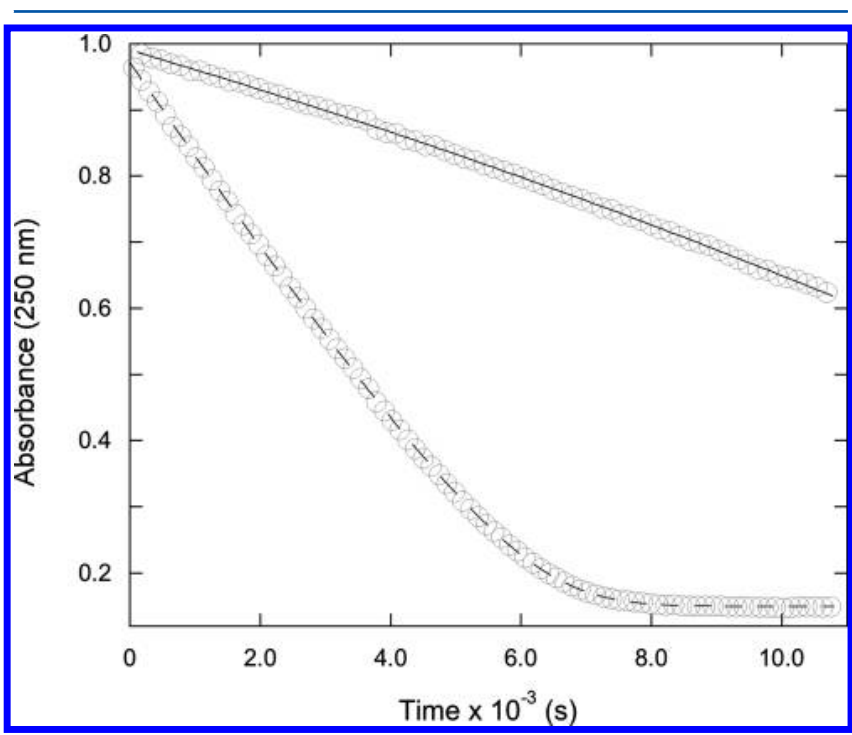

Figure 2. Progress curves showing turnover of substrate $14(0.5 \mathrm{mM})$ by the R39 DD-peptidase $(0.21 \mu \mathrm{M})$ in the absence $(---)$ and presence $(-)$ of $12(20 \mu \mathrm{M})$. The empty circles are experimental, and the lines represent fits of the data to Scheme 8 (see the text).

Scheme 8 , which was fit to data like those shown in Figure 1 (fit shown). The product, $\mathrm{Q}$ of the reaction of $\mathbf{1 2}$ with substrate

\section{Scheme 8}

\begin{tabular}{|rll}
\hline$E+S$ & $\rightleftharpoons$ & $E S$ \\
$E S$ & $\stackrel{k_{2}}{\longrightarrow} E+P$ \\
$E+I$ & $\rightleftharpoons$ & $E I$ \\
& & \\
$E S+1$ & $\stackrel{k_{3}}{\longrightarrow}$ & $E+Q$
\end{tabular}

14, which presumably is 30 , must be a weak inhibitor of the R39 enzyme. Acylation of $\mathbf{1 2}$ by $\mathbf{1 4}$ would lead to a gradual depletion of the inhibitor in solution and thus to a decreasing level of inhibition with time (Figure 1). The $K_{\mathrm{i}}$ value for 12 reported in Table 2 derives from the fits of these data. This phenomenon was not observed in the experiments with 12 and PBP4a or with 11 and both enzymes probably because of the higher concentrations of inhibitors required for the experiments, leading to smaller fractional depletions of the inhibitors in these cases.<smiles>CC(CCCCC(=O)NC(C)C(=O)O)NC(=O)CNC(=O)Cc1ccccc1</smiles>

Because of the complication created by the ability of 7 and 8 to act as strong acyl group acceptors, their activity as inhibitors, although weaker than that of $\mathbf{2}$ and $\mathbf{1 2}$, could not be readily determined from experiments in which turnover of the substrate was monitored. Therefore, the binding strengths of 7 and 8 were determined from the inhibition of their irreversible inactivation of the R39 enzyme with cefotaxime, monitored fluorimetrically. ${ }^{54}$ These measurements showed that 7 and 8 did in fact bind very weakly [at millimolar concentrations (Table 2)]. The fluorescence inhibition method was checked with 2 and 12, with acceptable results (Table 2).

It is also striking that $\mathbf{1 1}$ and $\mathbf{1 2}$ are more effective inhibitors of the R39 enzyme than of PBP4a. This may relate to the same order of reactivity of specific substrates with these enzymes. ${ }^{20}$ On the other hand, the analogous boronic acid $\mathbf{2}$ is a stronger inhibitor of PBP4a than of the R39 enzyme. The latter difference, however, may relate to the interesting observation that the binding of 2 to PBP4a is a slow (minutes; two-step?) process, ${ }^{20}$ whereas its binding to the R39 enzyme is fast (with respect to manual mixing times). No time dependence of the inhibition of either of these enzymes by 11 and 12 was observed.

Crystal Structure of the Complex of the R39 DDPeptidase with 12. An X-ray diffraction study of the title complex was performed. Initial electron density maps resulting from the molecular replacement were excellent for the four protein monomers present in the asymmetric unit, allowing a precise localization of $\mathbf{1 2}$ in the active site of each monomer (Figure 3). The inhibitor $\mathbf{1 2}$ is covalently bonded to the active serine Ser49; the carbonyl carbon is now tetrahedral, and the ketone oxygen occupies the oxyanion hole, defined by the backbone NH groups of Ser49 and Thr413. The D-methyl group is directed into a hydrophobic pocket comprised of residues Gly148, Leu349, and Met414. As previously observed in the structures of the R39 enzyme with boronic acid $2,{ }^{30}$ a cephalosporin or a peptide, ${ }^{26}$ each bearing an aminopimelic side chain, the aminopimelyl side chain runs along a hydrophobic groove and is fixed by a series of hydrogen bonds between the amido group and Asn300 N $\delta 2$ and Thr413 O atoms, and between the terminal $\mathrm{D}-\alpha$-amino acid moiety and the Arg351 guanidinium, the Asp142 carboxylate, and the Ser415 hydroxyl.

The most novel elements of the structure are the position of the trifluoromethyl group and its interaction with the enzyme active site. Branching from the tetrahedral carbon bonded to Ser49 $\mathrm{O} \gamma$, the $\mathrm{CF}_{3}$ group occupies the likely position of a leaving group in the tetrahedral intermediate of a peptidase substrate (and thus of one of the boronate hydroxyl groups in the analogous complex with $2^{30}$ ). An overlap of the active site elements of the boronate 2 complex and that of the trifluoroketone 12 , both bearing a free $\mathrm{D}-\alpha$-aminopimelyl 


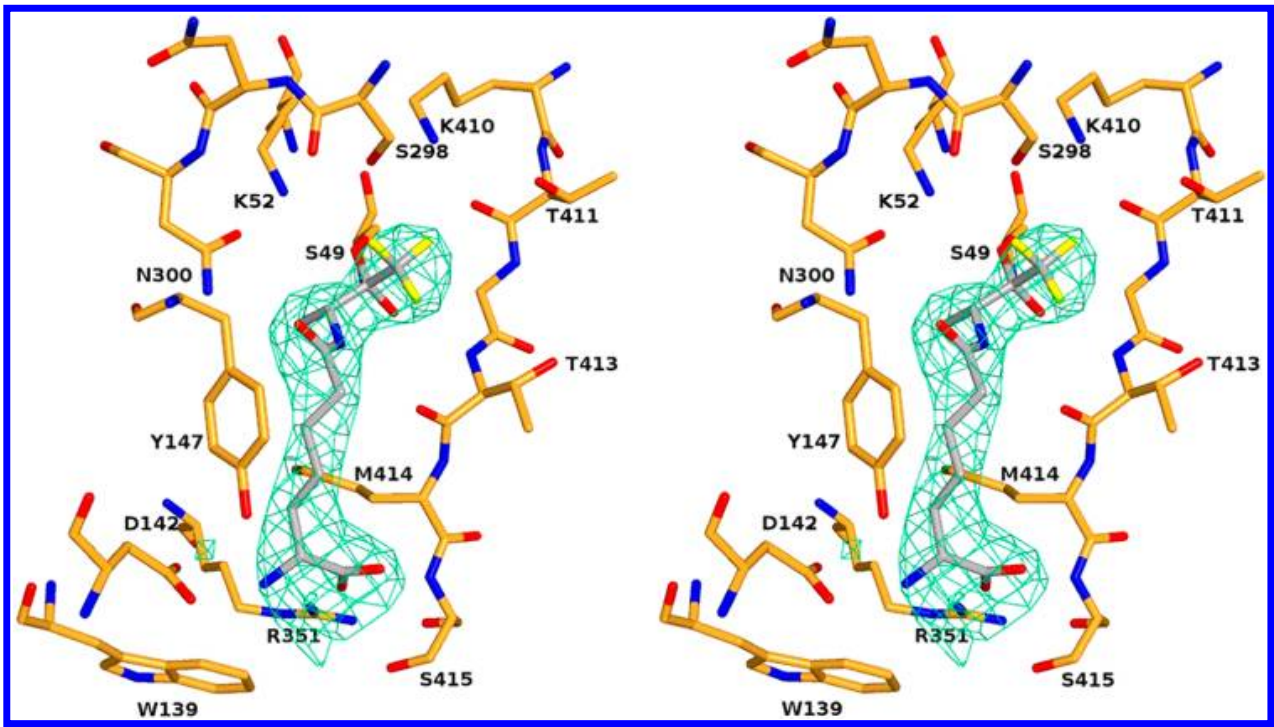

Figure 3. Crystal structure of the R39 DD-peptidase in complex with the specific trifluoroketone 12. In this stereoview, the electron density is an $\left|F_{\mathrm{o}}\right|-\left|F_{\mathrm{c}}\right|$ difference map calculated from the final coordinates of the model refined in the absence of ligand. The resulting positive density is shown with green hatching and is contoured at $2.5 \sigma$. The protein backbone and side chains are colored orange, and the trifluoroketone is colored gray. Heteroatoms are colored red (oxygen), blue (nitrogen), orange (sulfur), and yellow (fluorine). This figure was generated using PYMOL (http://www.pymol.sourceforge.net).

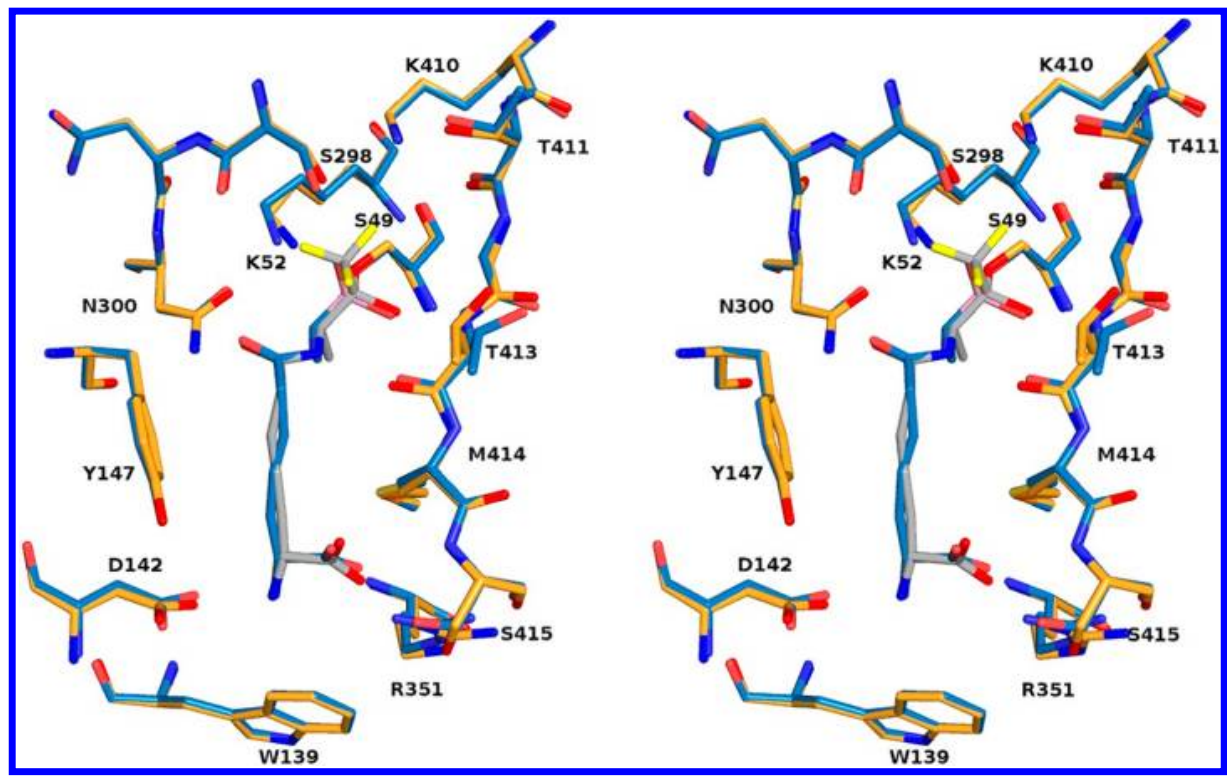

Figure 4. Superimposition of the active site residues of the complex of 12 with the R39 DD-peptidase on those of the analogous complex with boronic acid 2. ${ }^{30}$ In this stereoview, the colors of the complex of $\mathbf{1 2}$ are the same as those in Figure 3. The boronate complex is colored blue except for the heteroatoms, which are colored as in Figure 3, and boron, which is colored rose. This figure was generated using PYMOL (http:// www.pymol.sourceforge.net).

N-terminus, for which this enzyme is specific, ${ }^{20,24}$ is shown in Figure 4. The inhibitors are essentially identically placed in the active site, as would be expected for transition state analogues with such similar structure, with the $\mathrm{CF}_{3}$ group of 12 overlapping directly with the "leaving group" boronate hydroxyl. With respect to the position of the $\mathrm{CF}_{3}$ group, one $\mathrm{O}-\mathrm{C}-\mathrm{C}-\mathrm{F}$ dihedral angle is $57^{\circ}$, indicating an essentially precise staggering of the fluorine atoms with respect to the oxyanion $\mathrm{O}^{-}$. This conformation would be expected, of course, on steric and electrostatic grounds and has been observed in serine proteasetrifluoroketone complexes (for example, in ref 55). One fluorine atom is directed out of the active site into the solvent where it might well interact with water molecules in the manner observed in a variety of crystal structures. ${ }^{55-58}$ Such interactions are probably more dipolar in nature than those involving classical hydrogen bonding and are probably of $\sim 1 \mathrm{kcal} / \mathrm{mol}$ strength. ${ }^{59,60}$ The other two fluorine atoms appear to interact in a bifurcated fashion at a distance of $3.0 \AA$ each with the hydroxyl of Ser298. This kind of arrangement has been previously observed, for example, in a trifluoroketone adduct with chymotrypsin, ${ }^{55}$ where two fluorines interact with a water molecule, and in a thrombin complex, where a similar interaction with a water molecule has been observed. ${ }^{57}$ It is interesting that the Lys52 terminal nitrogen has not moved within $4.0 \AA$ of a fluorine atom. There are many examples of close $\mathrm{NH} \cdots \mathrm{F}$ interactions of $<3.0 \AA$ in complexes of enzymes with fluorinated 
inhibitors. ${ }^{55-58,61}$ In this case, the Lys52 amine would certainly be protonated, in a negatively charged transition state analogue structure as it is and where it is strongly interacting with Ser49 $\mathrm{O} \gamma(2.9 \AA)$ and $\mathrm{Asn} 300 \mathrm{O}_{\delta}(2.8 \AA)$ atoms.

A combination of the inhibition kinetics and the crystal structure, both discussed above, suggests that the trifluoromethyl moiety alone does not interact specifically and tightly with the DD-peptidase active site but acts only as part of an electrophilic ketone that does react with the active site serine in a cooperative fashion with the specifically binding D- $\alpha$-aminopimelyl N-terminus. ${ }^{26,27,30,62}$

\section{CONCLUSIONS}

Compound $\mathbf{1 2}$ represents the first nanomolar trifluoroketone inhibitor of a DD-peptidase. It owes its potency to the trifluoroketone moiety, elevating it over the less electrophilic aldehyde $\mathbf{1 1}$ and other tetrahedral species derived from 7-10, which occupy the active site less favorably. As shown by the very limited effectiveness of the generic analogues $\mathbf{2 4 - 2 7}$, it is clear that $\mathbf{1 2}$ is able to achieve its effectiveness only in combination with the strong specificity produced by the $\mathrm{D}-\alpha$-aminopimelyl terminus, whose affinity for certain LMMC DD-peptidases has been established. This combination of the trifluoroketone, which forms a tetrahedral adduct with the active site serine, and the D$\alpha$-aminopimelyl terminus into a complete inhibitor of the R39 DD-peptidase is seen very clearly in the crystal structure of the complex between the enzyme and 12. The trifluoroketone moiety and other activated carbonyls, therefore, should be considered along with boronic acids and phosphonates as warheads that can be incorporated into new and effective DD-peptidase inhibitors and therefore, perhaps, antibiotics.

\section{ASSOCIATED CONTENT}

\section{S Supporting Information}

Synthetic details for the preparation of compounds 7-11. This material is available free of charge via the Internet at http:// pubs.acs.org.

\section{AUTHOR INFORMATION}

\section{Corresponding Author}

*Telephone: (860) 685-2629. E-mail: rpratt@wesleyan.edu. Fax: (860) 685-2211.

\section{Funding}

This research was supported by National Institutes of Health Grant AI-17986 (R.F.P.) and in part by the Belgian Program on Interuniversity Poles of Attraction initiated by the Belgian State, Prime Minister's Office, Science Policy programming (IAP P6/ 19), the Fonds de la Recherche Scientifique (IISN 4.4505.09, IISN 4.4509.11, and FRFC 2.4511.06F), and the University of Liège (Fonds spéciaux, Crédit classique, C-06/19 and C-09/ 75). C.D. and F.K. are research associates of the FRS-FNRS, Belgium.

\section{Notes}

The authors declare no competing financial interest.

\section{ABBREVIATIONS}

DIBAL, diisobutylaluminum hydride; ESMS, electrospray ionization mass spectrometry; HBTU, O-(benzotriazol-1-yl)- $N, N, N^{\prime}, N^{\prime}$ tetramethyluronium hexafluorophosphate; HMM, high-molecular mass; HRMS, high-resolution mass spectrometry; LMM, lowmolecular mass; MES, 4-morpholinoethanesulfonic acid; MOPS, 3-morpholinopropanesulfonic acid; NMR, nuclear magnetic resonance; PBP, penicillin-binding protein; THF, tetrahydofuran.

\section{REFERENCES}

(1) Wise, E. M., and Park, J. T. (1965) Penicillin: Its basic site of action as an inhibitor of a peptide cross-linking reaction in cell wall mucopeptide synthesis. Proc. Natl. Acad. Sci. U.S.A. 54, 75-81.

(2) Tipper, D. J., and Strominger, J. L. (1965) Mechanism of action of penicillins: A proposal based on their structural similarity to acyl-Dalanyl-D-alanine. Proc. Natl. Acad. Sci. U.S.A. 54, 1133-1141.

(3) Lee, B. (1971) Conformation of penicillin as a transition-state analog of the substrate of peptidoglycan transpeptidase. J. Mol. Biol. 61, 463-469.

(4) Pratt, R. F. (2002) Functional evolution of the serine $\beta$-lactamase active site. J. Chem. Soc., Perkin Trans. 2, 851-861.

(5) Frère, J.-M., Ed. (2012) $\beta$-Lactamases, Nova, New York.

(6) Drawz, S. M., and Bonomo, R. A. (2010) Three decades of $\beta$ lactamase inhibitors. Clin. Microbiol. Rev. 23, 160-201.

(7) Bebrone, C., Lassaux, P., Vercheval, L., Sohier, J. S., Jehaes, A., Sauvage, E., and Galleni, M. (2010) Current challenges in antimicrobial chemotherapy: Focus on $\beta$-lactamase inhibition. Drugs $70,651-679$.

(8) Bush, K., and Macielag, M. J. (2010) New $\beta$-lactam antibiotics and $\beta$-lactamase inhibitors. Expert Opin. Ther. Pat. 20, 1277-1293.

(9) Miguet, L., Zervosen, A., Gerards, T., Pasha, F. A., Luxen, A., Distèche-Nguyen, M., and Thomas, A. (2009) Discovery of new inhibitors of Streptococcus pneumoniae penicillin-binding protein (PBP) $2 \mathrm{x}$ by structure-based virtual screening. J. Med. Chem. 52, 5926-5936.

(10) Turk, S., Verlaine, O., Gerards, T., Zivec, M., Humljan, J., Sosic, I., Amoroso, A., Zervosen, A., Luxen, A., Joris, B., and Gobec, S. (2011) New non-covalent inhibitors of penicillin-binding proteins from penicillin-resistant bacteria. PLoS One 6, e19418.

(11) Contreras-Martell, C., Amoroso, A., Woon, E. C. Y., Zervosen, A., Inglis, S., Martins, A., Verlaine, O., Rydzik, A. M., Job, V., Luxen, A., Joris, B., Schofield, C. J., and Dessen, A. (2011) Structure-guided design of cell wall biosynthesis inhibitors that overcome $\beta$-lactam resistance in Staphylococcus aureus (MRSA). ACS Chem. Biol. 6, 941951.

(12) Woon, E. C. Y., Zervosen, A., Sauvage, E., Simmonds, K. J., Zivec, M., Inglis, S. R., Fishwick, C. W. G., Gobec, S., Charlier, P., Luxen, A., and Schofield, C. J. (2011) Structure guided development of potent reversibly binding penicillin binding protein inhibitors. ACS Med. Chem. Lett. 2, 219-223.

(13) Dzhekieva, L., Kumar, I., and Pratt, R. F. (2012) Inhibition of bacterial DD-peptidases (penicillin-binding proteins) in membranes and in vivo by peptidoglycan-mimetic boronic acids. Biochemistry 51, 2804-2811.

(14) Shilabin, A. G., Dzhekieva, L., Misra, P., Jayaram, B., and Pratt, R. F. (2012) 4-Quinolones as non-covalent inhibitors of high molecular mass penicillin-binding proteins. ACS Med. Chem. Lett. 3, $592-595$.

(15) Fedarovich, A., Djordjevic, K. A., Swanson, S. M., Peterson, Y. K., Nicholas, R. A., and Davies, C. (2012) High-throughput screening for novel inhibitors of Neisseria gonorrhoeae penicillin-binding protein 2. PLoS One 7, e44918.

(16) Pauling, L. (1946) Molecular architecture and biological reactions. Chem. Eng. News 24, 1375-1377.

(17) Wolfenden, R. (1969) Transition state analogues for enzyme catalysis. Nature 223, 704-705.

(18) Schramm, V. L. (1998) Enzymatic transition states and transition state analog design. Annu. Rev. Biochem. 67, 693-720.

(19) Pratt, R. F. (2008) Substrate specificity of bacterial DDpeptidases (penicillin-binding proteins). Cell. Mol. Life Sci. 65, 21382155.

(20) Nemmara, V. V., Dzhekieva, L., Sarkar, K. S., Adediran, S. A., Duez, C., Nicholas, R. A., and Pratt, R. F. (2011) Substrate specificity of low-molecular mass bacterial DD-peptidases. Biochemistry 50, 10091-10101. 
(21) Ghuysen, J.-M. (1991) Serine $\beta$-lactamases and penicillinbinding proteins. Annu. Rev. Microbiol. 45, 37-67.

(22) Anderson, J. W., and Pratt, R. F. (2000) Dipeptide binding to the extended active site of the Streptomyces R61 D-alanyl-D-alaninepeptidase: The path to a specific substrate. Biochemistry 39, 1220012209.

(23) McDonough, M. A., Anderson, J. W., Silvaggi, N. R., Pratt, R. F., Knox, J. R., and Kelly, J. A. (2002) Structures of two kinetic intermediates reveal species specificity of penicillin-binding proteins. $J$. Mol. Biol. 322, 111-122.

(24) Anderson, J. W., Adediran, S. A., Charlier, P., Nguyen-Distèche, M., Frère, J.-M., Nicholas, R. A., and Pratt, R. F. (2003) On the substrate specificity of bacterial DD-peptidases: Evidence from two series of peptidoglycan-mimetic peptides. Biochem. J. 373, 949-955.

(25) Adediran, S. A., Kumar, I., Nagarajan, R, Sauvage, E., and Pratt, R. F. (2011) Kinetics of reactions of the Actinomadura R39 DDpeptidase with specific substrates. Biochemistry 50, 376-387.

(26) Sauvage, E., Powell, A. J., Heilemann, J., Josephine, H. R., Charlier, P., Davies, C., and Pratt, R. F. (2008) Crystal structures of complexes of bacterial DD-peptidases with peptidoglycan-mimetic ligands; the substrate specificity puzzle. J. Mol. Biol. 381, 383-393.

(27) Sauvage, E., Duez, C., Herman, R., Kerff, F., Petrella, S., Anderson, J. W., Adediran, S. A., Pratt, R. F., Frère, J.-M., and Charlier, P. (2007) Crystal structure of the Bacillus subtilis penicillin-binding protein $4 \mathrm{a}$ and its complex with peptidoglycan-mimetic peptide. J. Mol. Biol. 371, 528-539.

(28) Josephine, H. R., Charlier, P., Davies, C., Nicholas, R. A., and Pratt, R. F. (2006) Reactivity of penicillin-binding proteins with peptidoglycan-mimetic $\beta$-lactams: What's wrong with these enzymes? Biochemistry 45, 15873-15883.

(29) Kumar, I., Josephine, H. R., and Pratt, R. F. (2007) Reactions of peptidoglycan-mimetic $\beta$-lactams with penicillin-binding proteins in vivo and in membranes. ACS Chem. Biol. 2, 620-624.

(30) Dzhekieva, L., Rocaboy, M., Kerff, F., Charlier, P., Sauvage, E., and Pratt, R. F. (2010) Crystal structure of a complex between the Actinomadura R39 DD-peptidase and a peptidoglycan-mimetic boronate inhibitor: Interpretation of a transition state analogue in terms of catalytic mechanism. Biochemistry 49, 6411-6419.

(31) Zervosen, A., Bouillez, A., Herman, R., Amoroso, A., Joris, B., Sauvage, E., Charlier, P., and Luxen, A. (2012) Synthesis and evaluation of boronic acids as inhibitors of penicillin binding proteins of classes A, B, and C. Bioorg. Med. Chem. 20, 3915-3924.

(32) Kraut, J. (1977) Serine proteases: Structure and mechanism of catalysis. Annu. Rev. Biochem. 46, 331-358.

(33) Pechenov, A., Stefanova, M. E., Nicholas, R. A., Peddi, S., and Gutheil, W. G. (2003) Potential transition state analogue inhibitors for the penicillin-binding proteins. Biochemistry 42, 579-588.

(34) Granier, B., Duez, C., Lepage, S., Englebert, S., Dusart, J., Dideberg, O., Van Beeumen, J., Frère, J. M., and Ghuysen, J. M. (1992) Primary and predicted secondary structures of the Actinomadura R39 extracellular DD-peptidase, a penicillin-binding protein (PBP) related to the Escherichia coli PBP4. Biochem. J. 282, 781-788. (35) Duez, C., Van Hove, M., Gallet, X., Bouillene, F., Docquier, J.D., Brans, A., and Frère, J.-M. (2001) Purification and characterization of PBP4a, a new low molecular-weight penicillin-binding protein from Bacillus subtilis. J. Bacteriol. 183, 1595-1599.

(36) Rodriquez, M., and Taddei, M. (2005) A simple procedure for the transformation of L-glutamic acid into the corresponding $\gamma$ aldehyde. Synthesis, 493-495.

(37) McBee, E. T., Hathaway, C. E., and Roberts, C. W. (1956) The ethanolysis of 1,1,1-trifluoro-2,3-epoxybutane and 2-methyl-1,1,1trifluoro-2,3-epoxypropane. J. Am. Chem. Soc. 78, 4053-4057.

(38) Shao, Y. M., Yang, W. B., Kuo, T. H., Tsai, K. C., Lin, C. H., Yang, A. S., Liang, P. H., and Wong, C. H. (2008) Design, synthesis, and evaluation of trifluoromethyl ketones as inhibitors of SARS-CoV 3CL protease. Bioorg. Med. Chem. 16, 4652-4660.

(39) Kuzmic, P. (1996) Program DYNAFIT for the analysis of enzyme kinetic data: Application to HIV proteinase. Anal. Biochem. $237,260-273$.
(40) Murshudov, G. N., Vagin, A. A., and Dodson, E. J. (1997) Refinement of macromolecular structures by the maximum-likelihood method. Acta Crystallogr. D53, 240-255.

(41) Emsley, P., and Cowtan, K. (2004) Coot: Model-building tools for molecular graphics. Acta Crystallogr. D60, 2126-2132.

(42) Painter, J., and Merritt, E. A. (2006) Optimal description of a protein structure in terms of multiple groups undergoing TLS motion. Acta Crystallogr. D62, 439-450.

(43) Bégué, J.-P., Bonnet-Delpon, D., Fischer-Durand, N., Amour, A., and Reboud-Ravaux, M. (1994) Stereoselective synthesis and inhibitor properties towards human leucocyte elastase of chiral $\beta$-peptidyl trifluoromethyl alcohols. Tetrahedron: Asymmetry 5, 1099-1110.

(44) Potetinova, J. V., Voyushina, T. L., and Stepanov, V. M. (1997) Enzymatic synthesis of peptidyl-amino aldehydes-serine proteinase inhibitors. Bioorg. Med. Chem. Lett. 7, 705-710.

(45) Rahil, J., and Pratt, R. F. (1992) Mechanism of inhibition of the class C $\beta$-lactamase of Enterobacter cloacae P99 by phosphonate monoesters. Biochemistry 31, 5869-5878.

(46) Silvaggi, N. R., Anderson, J. W., Brinsmade, S. A., Pratt, R. F., and Kelly, J. A. (2003) The crystal structure of phosphonate-inhibited D-Ala-D-Ala peptidase reveals an analogue of a tetrahedral transition state. Biochemistry 42, 1199-1208.

(47) Allen, K. N., and Abeles, R. H. (1989) Inhibition kinetics of acetylcholinesterase with fluoromethyl ketones. Biochemistry 28, $8466-8473$.

(48) Jencks, W. P., and Regenstein, J. (1975) in Handbook of Biochemistry and Molecular Biology (Fassman, G. D., Ed.) 3rd ed., Vol. 1, pp 305-351, CRC, Cleveland, OH.

(49) Guthrie, J. P. (1975) Carbonyl addition reactions: Factors affecting the hydrate-hemiacetal and hemiacetal-acetal equilibrium constants. Can. J. Chem. 53, 898-906.

(50) Smith, R. A., Copp, L. J., Donnelly, S. L., Spencer, R. W., and Krantz, A. (1988) Inhibition of cathepsin B by peptidyl aldehydes and ketones: Slow-binding behavior of a trifluoromethyl ketone. Biochemistry 27, 6568-6573.

(51) Imperiali, B., and Abeles, R. H. (1986) Inhibition of serine proteases by peptidyl fluoromethyl ketones. Biochemistry 25, 37603767.

(52) Angelastro, M. R., Baugh, L. E., Bey, P., Burkhart, J. P., Chen, T.M., Durham, S. L., Hare, C. M., Huber, E. W., Janusz, M. J., Koehl, J. R, Marquart, A. L., Mehdi, S., and Peet, N. P. (1994) Inhibition of human neutrophil elastase with peptidyl electrophilic ketones 2 . Orally active $\mathrm{P}_{\mathrm{G}}$-Val-Pro-Val pentafluoroethyl ketones. J. Med. Chem. 37, $4538-4554$.

(53) Stamper, C. G. F., Morello, A. A., and Ringe, D. (1998) Reaction of alanine racemase with 1-aminoethylphosphonic acid forms a stable external aldimine. Biochemistry 37, 10438-10445.

(54) Fuad, N., Frère, J.-M., Ghuysen, J.-M., Duez, C., and Iwatsubo, M. (1976) Mode of interaction between $\beta$-lactam antibiotics and the exocellular DD-carboxypeptidase-transpeptidase from Streptomyces R39. Biochem. J. 155, 623-629.

(55) Brady, K., Wei, A., Ringe, D., and Abeles, R. H. (1990) Structure of chymotrypsin-trifluoromethyl ketone inhibitor complexes: Comparison of slowly and rapidly equilibrating inhibitors. Biochemistry 29, $7600-7607$.

(56) Bernstein, P. R., Gomes, B. C., Kosmider, B. J., Vacek, E. P., and Williams, J. C. (1995) Nonpeptidic inhibitors of human leukocyte elastase. 6. Design of a potent, intratracheally active, pyridone-based trifluoromethyl ketone. J. Med. Chem. 38, 212-215.

(57) Salvagnini, C., Michaux, C., Remiche, J., Wouters, J., Charlier, P., and Marchand-Brynaert, J. (2005) Design, synthesis and evaluation of graftable thrombin inhibitors for the preparation of blood-compatible polymer materials. Org. Biomol. Chem. 3, 4209-4220.

(58) Nielsen, T. K., Hildmann, C., Riester, D., Wegener, D., Schwienhorst, A., and Ficner, R. (2007) Complex structure of a bacterial class 2 histone deacetylase homologue with a trifluoromethylketone inhibitor. Acta Crystallogr. F63, 270-273. 
(59) Caminati, W., Melandri, S., Maris, A., and Ottaviani, P. (2006) Relative strengths of the $\mathrm{OH} \cdots \mathrm{Cl}$ and $\mathrm{OH} \cdots \mathrm{F}$ hydrogen bonds. Angew. Chem., Int. Ed. 45, 2438-2442.

(60) Muller, K., Faeh, C., and Diederich, F. (2007) Fluorine in pharmaceuticals: Looking beyond intuition. Science 317, 1881-1886.

(61) Dalvit, C., and Vulpetti, A. (2012) Intermolecular and intramolecular hydrogen bonds involving fluorine atoms: Implications for recognition, selectivity, and chemical properties. ChemMedChem 7, 262-272.

(62) Majumdar, S., and Pratt, R. F. (2009) Intramolecular cooperativity in the reaction of diacyl phosphates with serine $\beta$ lactamases. Biochemistry 48, 8293-8298.

(63) Lovell, S. C., Davis, I. W., Arendall, W. B., III, de Bakker, P. I., Word, J. M., Prisant, M. G., Richardson, J. S., and Richardson, D. C. (2003) Structure validation by $\mathrm{C} \alpha$ geometry: $\phi, \psi$ and $\mathrm{C} \beta$ deviation. Proteins 50, 437-450. 